\title{
Nutritional Deficiencies of Clarified White Grape Juices and Their Correction in Relation to Fermentation
}

\author{
A.C. Houtman and C.S. du Plessis \\ Viticultural and Oenological Research Institute, Private Bag X5026, 7600 Stellenbosch, Republic of South Africa. \\ Submitted for publication: January 1986 \\ Accepted for publication: April 1986 \\ Keywords: grape must, retarded fermentation, yeast nutrition, ergosterol, fatty acids, nitrogen.
}

\begin{abstract}
Juice filtrates of grape samples of the cultivars Cape Riesling, Chenin blanc and Colombar from different wine regions of South Africa, were fermented under standardised anaerobic conditions at a temperature of $15^{\circ} \mathrm{C}$. Juice clarification reduced fermentation rates but marked differences between the cultivars were observed. Whereas most of the Cape Riesling filtrates fermented dry at a moderate rate, fermentation of the Colombar juice filtrates were strongly retarded or lagged. The Chenin blanc juices fermented at a rate intermediate to these two. It was established that all slow fermentations were caused by nutritional deficiencies of the juices as a result of filtration and that fermentation could be restored to normal by addition of combinations of ergosterol and unsaturated fatty acids.
\end{abstract}

The fermentation rate of grape must and hence also the fermentation time are not only important in the formation of the fermentation bouquet and consequently wine quality, but also have major economic implications as they affect the production capacity, and thus the financial return, of wine cellars. Effective mangement can also be more readily achieved by the possibility of accurately predicting the duration of fermentation.

During the sixties formulas were developed to predict fermentation rate using variables such as sugar, acid contents, $\mathrm{pH}$, temperature, nitrogen, and biotin concentrations (Ough \& Amerine, 1961; Ough, 1964; Ough, 1966a, 1966b; Ough \& Amerine, 1966; Ough \& Kunkee, 1967, 1968). These formulas were empiric and did not include important variables such as juice turbidity and oxygen concentration. Consequently, in practice, the use of these formulas failed to forecast fermentation rates accurately. It is well-known that fermentations can be completed in a very short time by the use of incompletely clarified juice, by aeration or by the implementation of high fermentation temperatures. However, such conditions are in conflict with established principles for the production of quality white wine where free-run juice, effective juice clarification, exclusion of air and low fermentation temperatures are required for the production of the fruity wine types (Wucherpfennig \& Bretthauer, 1970; Ribéreau-Gayon, Lafon-Lafourcade \& Bertrand, 1975; Singleton et al., 1975; Bertrand, Marly-Brugerolle \& Sarre, 1978; Ribéreau-Gayon, Sudraud \& Lafon-Lafourcade 1978; Wenzel \& Dittrich, 1978; Williams, Ough \& Berg, 1978; Buteau, Duitschaever \& Ashton, 1979; Castino, Ubigli \& Di Stefano, 1980; Houtman, Marais \& Du Plessis, 1980a; Bertrand \& Miele, 1984; Tromp, 1984). However, if these fermentation conditions are too stringently applied, especially with regard to juice clarification, fermentation will be retarded or may even lag (Wucherpfennig \& Bretthauer, 1970; Ribéreau-Gayon, Lafon-Lafourcade \& Bertrand, 1975; Haubs, 1976; Groat \& Ough, 1978; Lafon-Lafourcade \& RibéreauGayon, 1979; Houtman, Marais \& Du Plessis, 1980a, 1980b; Houtman \& Du Plessis, 1981; Lafon-Lafourcade, Geneix \& Ribéreau-Gayon, 1984; Tromp, 1984). In this respect Houtman \& Du Plessis (1986) found that fermentations of juice filtrates of the grape cultivars Colombar, Chenin blanc, Sémillon, Cape Riesling and Muscat d'Alexandrie under strictly anaerobic conditions at $15^{\circ} \mathrm{C}$ required an average of 60 days. In the case of the first three cultivars fermentations often lagged and sugar residues of from 10 to $50 \mathrm{~g} . \mathrm{l}^{-1}$ were found (Houtman \& Du Plessis, 1981, 1986.) These authors found that Cape Riesling and Muscat d'Alexandrie juices which were clarified by no. 3 filters, fermented relatively slowly but most fermentations were completed. However, after clarification by EK-filtration the same juices frequently gave rise to lagging fermentation. Evidently the heterogeneous material causing turbidity in grape juice contains a finely dispersed fraction which is essential for active yeast proliferation and fermentation. A very small amount of this fraction was effective in bringing about good fermentation as shown by high fermentation rates in juice filtrates to which $10 \%$ or $20 \%$ of settled juice had been added (Houtman et al., 1980a; Houtman \& Du Plessis, 1981). The degree of dispersion and the filterability of this yeast growthpromoting turbidity fraction differed from juice to juice (Houtman \& Du Plessis, 1981, 1986).

There are many indications that these essential yeast nutrition substances occur in the finely emulsified oily fraction of the juice turbidity (Bertrand \& Miele, 1984; Houtman \& Du Plessis, 1986). Anaerobiosis is only possible during a limited period if no unsaturated lipids are present in the medium. A great variety of fatty compounds may serve in this respect for instance unsaturated fatty acids, phospholipids, sterols, carotenoids and squalene. In all these cases the unsaturation in the molecule restores the yeast proliferation ability. Under aerobic conditions yeast can dehydrogenate fatty acids to unsaturated fatty acids, which can, under anaerobic conditions, serve as hydrogen acceptors in its metabolism (Nordheim, 1965; Linnane \& Kellermann, 1971). Similar observations were made with regard to unsaturated steroids such as ergosterol, lanosterol and 
episterol (David \& Kirsop, 1973; Haukeli \& Lie, 1973; David, 1974).

The ergosterol content of yeast cells proliferating under anaerobic conditions is rapidly depleted to a minimum of $1 \mathrm{mg} \cdot \mathrm{g}^{-1}$ (dry mass) at which level it is incapable of further growth. Such yeasts are therefore unsuitable as an inoculum. In contact with air yeasts produce ergosterol very rapidly, viz. up to $5 \mathrm{mg}^{-\mathrm{g}^{-1}}$ in 20 minutes and thereafter more slowly to a maximum of $10 \mathrm{mg} \cdot \mathrm{g}^{-1}$. Yeast cells are then in an optimal condition to function as an inoculum (Aries \& Kirsop, 1977, 1978; Kirsop, 1978; Strydom, Kirschbaum \& Tromp, 1982).

Brechot et al., (1966, 1971a, 1971b) found that extracts of the wax layer of grape skins contains oleanolic acid which is able to stimulate yeast growth and fermentation rate in a synthetic medium as well as in grape juice under anaerobic conditions. Additions of ergosterol with Tween 80 detergent had a similar result. Sapis Domercq \& Peynaud (1973) accelerated anaerobic fermentation by heat treatment of the grape mash before juice separation, and ascribed this effect to steroids and unsaturated fatty acids from the grape solids. Ergosterol, added to grape juice in a finely dispersed (microcrystalline) form, had a considerable effect on yeast growth and fermentation rate provided that it was added at the time of inoculation (Houtman, et al., 1980a). Additions of ergosterol/Tween 80 combinations were more effective, even when added to a slowly fermenting must at a later stage (Houtman \& Du Plessis, 1981). Investigations with excessive additions of 25 to $100 \mathrm{mg} . \mathrm{l}^{-1}$ were less effective than additions of $20 \%$ or even $10 \%$ by volume of settled juice to the filtrates. Lagging fermentations could be corrected even on the 45th day by ergosterol/Tween 80 mixtures, and fermented dry (Houtman, et al., 1980a; Houtman \& Du Plessis, 1981). It is understandable that insoluble lipids will only be assimilable by yeasts in a finely emulsified form, and indeed it is known that fermentation stimulating agents must be very finely dispersed.

Recent studies do not ascribe the prevention of lagging fermentation by steroids to stimulated yeast proliferation but to an extension of the active life phase of the yeast cells. These steroids were therefore designated as "survival factors" (Lafon-Lafourcade et al., 1977; Larue, Lafon-Lafourcade \& Ribéreau-Gayon, 1978, 1979; Lafon-Lafourcade \& Ribéreau-Gayon, 1979; Lafon-Lafourcade, 1980). The role of steroids as "survival factors" for yeast in the final phase of fermentation was confirmed by Traverso-Rueda \& Kunkee (1982). Because fermentation rate in such cases is increased from the beginning of fermentation, it can only be explained as a yeast growth and fermentation enhancing effect (Houtman et al., 1980a; Houtman \& Du Plessis, 1981).

The key position of oxygen in the production of unsaturated lipids has already been mentioned. During yeast growth the first few generations of yeast can still be produced without oxygen using the ergosterol and unsaturated fatty acid supply of the inoculum. Consequently, air contact during the first 24 hours after inoculation has very little effect on fermentation rate, but fermentation is greatly enhanced by an aeration of the head space on the second or third day after inoculation when the number of cells has already increased consid- erably and their supply of ergosterol and unsaturated fatty acids have been exhausted (Lafon-Lafourcade, 1980; Soufleros \& Bertrand, 1980; Houtman \& Du Plessis, 1986). Such an aeration is detrimental to wine quality as the yeast, thus stimulated in the beginning of the exponential fermentation phase, induces a sharp drop in the redox potential and a resulting formation of $\mathrm{H}_{2} \mathrm{~S}$-like odours when the oxygen supply is suddenly withdrawn (Houtman \& Du Plessis, 1981).

A factor which can also affect fermentation rate is the yeast strain. There are great differences in the fermentation rates which different yeast strains can maintain as well as in their ergosterol requirements and ability to complete fermentation. Other specific differences among yeast strains appear in the length of lag time after inoculation (Tromp, 1984; Houtman \& Du Plessis, 1986). The amount of the inoculum, which seems to be independent of the yeast strain also affects both the lag time and overall rate of fermentation. In the case of small inoculums $\left(0,8 \times 10^{9}\right.$ live cells. $\left.l^{-1}\right)$ more yeast cells have to be produced than is the case with large inoculums. The lag time before which fermentation is perceivable is therefore longer. In settled juices yeast proliferation is sufficiently supported by the medium and fermentation curves are parallel and congruent, irrespective of the inoculation concentration (Lewis \& Enevoldsen, 1973; Houtman \& Du Plessis, 1981). On the other hand, in over clarified juices fermentation depends largely on the amount of unsaturated fatty acids and steroids in the inoculum. With a small inoculum these substances are soon exhausted and yeast proliferation becomes inadequate, causing the fermentation rate to drop considerably before fermentation is completed. With such juices far better results are obtained with large inoculums of up to $c a 2 \mathrm{x}$ $10^{10}$ live cells per litre, enriched with ergosterol by aeration shortly before use (Houtman \& Du Plessis, 1981).

The possibility of turbidity-producing particles stimulating fermentation mechanically by acting as "carriers" of yeast cells and thus keeping the yeast "floating" and more evenly distributed in the must, was investigated by the addition of artificial turbidity-producing materials such as bentonite, diatomaceous earth, talc or polyamide powder to the must (RibéreauGayon et al., 1975; Haubs, 1976; Groat \& Ough, 1978; Tromp 1984). However, these authors differed in opinion on the effect of these substances on fermentation rate and it is more generally accepted at present that lagging fermentation in clarified juices should be attributed partially to nutritional deficiencies of the medium.

Critical nutritive substances can also be lost from the juice by clarification with bentonite, which may cause lagging fermentation. It is therefore recommended, that bentonite, added to the juice for protein stabilisation, should remain in the must during fermentation (Petro, 1965; Ponomarchenko \& Albot, 1976; Bach \& Hoffmann, 1979; Tsakov et al., 1979).

A shortage of assimilable nitrogen is frequently mentioned as a cause of retarded fermentation (Bizeau, 1963; Lewis \& Enevoldsen, 1973; Wenzel \& Dittrich, 1978; Vos \& Gray, 1979; Tromp, 1984). Bizeau (1963) also noted the possibility of phosphorus and mineral deficiencies. Retarded fermentations have also been ascribed to vitamin deficiencies, i.a. thiamine, pantothen- 
ic acid and biotin, but then mostly in combination with other factors (Ough \& Kunkee, 1968; Ribéreau-Gayon et al., 1975; Lafon-Lafourcade \& Ribéreau-Gayon, 1979; Larue, Lafon-Lafourcade \& Ribéreau-Gayon, 1979; Ribéreau-Gayon et al., 1979; Minàrik, 1983). There are, however, no indications that vitamin deficiencies often occur in grape must.

Antibiotics excreted by Botrytis cinerea and pesticide residues are mentioned as causes of retarded fermentation (Ribéreau-Gayon et al., 1979; Lafon-Lafourcade, 1980). On the other hand, Minàrik (1983) obtained a yeast growth promoting extract from $B$. cinerea. It would appear that poisoning of the yeast by such external influences is sporadic and does not cause any serious problems.

Like ethanol, octanoic acid and decanoic acid are fermentation retardants which are produced during the fermentation process (Nordström, 1964; Geneix, Lafon-Lafourcade \& Ribéreau-Gayon, 1983; Lafon-Lafourcade, 1984; Larue et al., 1984). These fermentation retarding fatty acids can be absorbed from extracted yeast cell-wall material added to the must thus enhancing the rate of fermentation (Geneix et al., 1983; LafonLafourcade, 1984; Lafon-Lafourcade, Geneix \& Ribéreau-Gayon, 1984; Larue et al., 1984). However, the effect of added cell-wall material, can more convincingly be attributed to the fact that it also serves as a source of essential yeast nutrients (Bertrand \& Miele, 1984).

It is clear that radically clarified grape juice often is an inadequate medium if smooth and complete fermentation, as well as good wine quality, is to be achieved. However, cellars can generally obtain satisfactory results if juice clarification and anaerobiosis are not too drastic, selected yeasts with low nutritive requirements are used and mass inoculation is applied.

Apart from these aspects differences between the fermentability of juice samples on a cultivar basis have been observed (Houtman \& Du Plessis, 1986). Cape Riesling and Muscat d'Alexandrie juice filtrates were more suited as a medium for yeast proliferation than Chenin blanc and Colombar. Apparently the fermentation promoting turbidity fraction in the former two cultivar samples was more finely dispersed and filterable than in the latter two (Houtman \& Du Plessis, 1986). It is important that the nature of components contributing to effective fermentation of grape juices be identified. The aim of this study was to gain insight into the nature of compounds involved in fermentation differences between specific South African grape cultivars.

\section{MATERIALS AND METHODS}

\section{Juice preparation and fermentation:}

Wines were made from Chenin blanc, Cape Riesling and Colombar grapes from the Stellenbosch, Lynedoch, Paardeberg, Paarl, Huguenot, Robertson and Lutzville areas.

Free run juice was collected and settled overnight at approximately $3^{\circ} \mathrm{C}$. The sulphur dioxide content was corrected to $\mathrm{ca} 75 \mathrm{mg} . l^{-1}$ prior to inoculation. Juice was filtered after settling through no. 3 filter sheets which was followed by an EK-filtration. All juice was saturated with carbon dioxide and all subsequent manipulations carried out anaerobically in a closed system under this gas. Juice samples were all held at $-25^{\circ} \mathrm{C}$ in 5 litre glass containers until required.

An inoculation of 0,2 g. $l^{-1}$ dry yeast (Saccharomyces cerevisiae; WE 14 of VORI collection) was used. Living cell counts were $\mathrm{ca} 8,8 \mathrm{\times} 10^{8}$ cells. $l^{-1}$ per inoculation. Standardised anaerobic fermentations were carried out in five-fold with 0,4 litre juice samples (Houtman \& Du Plessis, 1981,1986$)$ at $15^{\circ} \mathrm{C}$.

\section{Treatments:}

All juices received $0,4 \mathrm{~g} . l^{-1}$ di-ammonium phosphate, $0,45 \mathrm{mg} . \mathrm{l}^{-1}$ thiamine and $0,07 \mathrm{mg} . \mathrm{l}^{-1}$ biotin. Twenty percent $(\mathrm{v} / \mathrm{v})$ solutions were made of yeast extract, malt extract and peptone and briefly heated to $100^{\circ} \mathrm{C}$. Tomato juice was clarified by filtration and used as such. Additions of these water soluble nutrients were given in volumes which, either in combinations or individually contained, per addition approximately $100 \mathrm{mg} . \mathrm{l}^{-1}$ nitrogen (expressed as $\mathrm{NH}_{3}$ ) as determined from their specified nitrogen contents. Since the effects of individual or combined additions were practically similar their results were consequently combined and their mean values used.

The unsatured fatty acids oleic, linoleic and linolenic (60-300 mg. $\left.l^{-1}\right)$ were added individually or in combinations with or without ergosterol $\left(15-25 \mathrm{mg} . l^{-1}\right)$.

The ergosterol (finely powdered) was dissolved in the slightly warmed mixtures of the fatty acids. All mixtures were finally diluted with $0,1 \mathrm{ml}$ ethanol and saponified in $20 \mathrm{ml} 0,3 \%(\mathrm{~m} / \mathrm{v})$ potassium hydroxide. The results of the different fatty acid additions showed little difference and were consequently combined.

\section{Fermentation rates and times:}

Carbon dioxide mass loss was determined over time. Fermentation times were determined over two periods viz. the time required for sugar consumption from 5-50 percent (Ft 5-50) and the fermentation time from 0-99 percent of sugar consumption (Ft 0-99) (Houtman \& Du Plessis, 1986). In cases of lagging fermentation the 99 percent point was determined by extrapolation.

In this study fermentations between 0-99 percent sugar utilisation which were regarded as non-retarded, retarded or lagging between sugar concentrations of $150-240$ g. $l^{-1}$ in the juice, were empirically defined as given below.

1. Juice fermentations were regarded as non-retarded if the times taken to ferment were less than the values given by the following formula:

time limit $=25+\frac{\left.\text { (juice sugar in } \mathrm{g} \cdot l^{-1}-150\right)}{3}$ days

For 150 to 240 g. $l^{-1}$ sugar these values are 25 to 55 days.

2. Juice fermentations were regarded as lagging if the time taken to ferment exceeded the values given by the following formula:

time limit $=55+\frac{\left.\text { (juice sugar in } \mathrm{g} . l^{-1}-150\right)}{3}$ days

For 150 to 240 g. $l^{-1}$ sugar these values are 55 to 85 days.

3. Juice fermentations were regarded as retarded if the times taken to ferment juice with sugar concentrations between 150 and 240 g. $l^{-1}$ were between the values given for non-retarded and lagging fermentations under 1 and 2.

\section{RESULTS AND DISCUSSION}

During filtration of grape juice through no. 3 filter it was found that due to partial blockage of the filter by 
grape particles, it later passed only exceptionally small particles (Houtman \& Du Plessis, 1981). These filtrates were such that their fermentation characteristics closely resembled those of EK-filtrates. As a result of this phenomenon the data from no. 3 and EK-filtered juices were combined.

Differences in fermentability of juice filtrates of three grape cultivars:

Marked differences were found between the juices of the cultivars Cape Riesling, Chenin blanc and Colom-

TABLE 1

Analytical data and fermentation times $(\mathrm{Ft})$ of juice filtrates from three grape cultivars.

\begin{tabular}{|c|c|c|c|c|c|c|}
\hline \multirow[t]{3}{*}{ Component/Period } & \multicolumn{2}{|c|}{ Cape Riesling } & \multicolumn{2}{|c|}{ Chenin blanc } & \multicolumn{2}{|c|}{ Colombar } \\
\hline & \multicolumn{6}{|c|}{ Analysis } \\
\hline & $\begin{array}{l}\text { Mean } \\
\text { value }\end{array}$ & $\mathrm{Cv}$ & $\begin{array}{l}\text { Mean } \\
\text { value }\end{array}$ & $\mathrm{Cv}$ & $\begin{array}{l}\text { Mean } \\
\text { value }\end{array}$ & $\mathrm{Cv}$ \\
\hline $\begin{array}{l}\text { Sugar }\left(\mathrm{g} . l^{1}\right) \\
\text { Total acid }\left(\mathrm{g} . l^{-1}\right) \\
\mathrm{pH} \\
\mathrm{SO}_{2}: \text { Free }\left(\mathrm{mg} . l^{-1}\right) \\
\quad \text { Total }\left(\mathrm{mg} . l^{-1}\right)\end{array}$ & $\begin{array}{l}190 \\
4,4 \\
3,59 \\
25 \\
48\end{array}$ & $\begin{array}{r}8 \\
15 \\
5 \\
24 \\
31\end{array}$ & $\begin{array}{l}192 \\
6,4 \\
3,37 \\
35 \\
65\end{array}$ & $\begin{array}{r}10 \\
16 \\
5 \\
31 \\
28\end{array}$ & $\begin{array}{c}196 \\
7,1 \\
3,31 \\
47 \\
80\end{array}$ & $\begin{array}{r}11 \\
15 \\
6 \\
19 \\
29\end{array}$ \\
\hline Total $\left(\mathrm{mg} . l^{-1}\right)$ & \multicolumn{6}{|c|}{ Fermentation times (days) } \\
\hline & $\mathrm{Ft}$ & $\mathrm{Cv}$ & $\mathrm{Ft}$ & $\mathrm{Cv}$ & $\mathrm{Ft}$ & $\mathrm{Cv}$ \\
\hline $\begin{array}{l}5 \text { to } 50 \% \text { (Ft } 5-50) \\
0 \text { to } 99 \% \text { (Ft } 0-99)\end{array}$ & $\begin{array}{l}5,1 \\
38\end{array}$ & $\begin{array}{l}18 \\
32\end{array}$ & $\begin{array}{l}6,2 \\
48\end{array}$ & $\begin{array}{l}24 \\
23\end{array}$ & $\begin{array}{c}6,6 \\
53\end{array}$ & $\begin{array}{l}17 \\
19\end{array}$ \\
\hline
\end{tabular}

Cv: Coefficient of variation (\%)

TABLE 2

Classification of juices according to cultivar and fermentation rate

\begin{tabular}{l|c|c|c}
\hline \multirow{2}{*}{ Fermentation rate class } & \multicolumn{3}{|c}{ Number of juice samples per cultivar } \\
\cline { 2 - 4 } & $\begin{array}{c}\text { Cape } \\
\text { Riesling }\end{array}$ & $\begin{array}{c}\text { Chenin } \\
\text { blanc }\end{array}$ & Colombar \\
\hline Non-retarded & 9 & 3 & 1 \\
Retarded & 2 & 11 & 3 \\
Lagging & 1 & 4 & 6 \\
\hline
\end{tabular}

bar with regard to analytical data and fermentation times (Table 1). Total acid and free and total sulphur dioxide concentrations in Colombar juices were always considerably higher and $\mathrm{pH}$ lower than in the Cape Riesling juices. The $\mathrm{SO}_{2}$ content of the Colombar juices was close to the added concentration of $75 \mathrm{mg} . l^{-1}$ whereas in the Cape Riesling juices roughly half of this value was found (Table 1). Obviously the grape solids in the Cape Riesling mash have a rather strong $\mathrm{SO}_{2}$-binding capacity. However, these differences between Colombar and Cape Riesling, in themselves, give no sufficient explanation for the higher fermentation rates of the Cape Riesling juices. None of these tabulated data are critically high or low with respect to fermentation retardation and these fermentations were not impaired or stimulated by varying of their $\mathrm{pH}$ or $\mathrm{SO}_{2}$ concentrations within these ranges (A.C. Houtman, unpublished data). Nevertheless, these $\mathrm{pH}$ and $\mathrm{SO}_{2}$ differences could be additional retarding factors in juices with nutritional deficiencies.

The forty juices and their fermentation times up to $99 \%$ sugar consumption were distributed over three fermentation rate classes viz. non-retarded, retarded and lagging (Table 2). These results confirm the observations on a smaller scale with the same grape cultivars over the last five years (A.C. Houtman, unpublished data). The most obvious differences are those between Cape Riesling and Colombar juices where the former fermented at a faster rate than the latter. Chenin blanc generally fermented at a rate between that of Cape Riesling and Colombar (Table 2).

\section{Water-soluble nutrients and unsaturated lipids:}

Table 3 shows that retardation of fermentation in the thoroughly clarified juices could be attributed entirely to nutritional deficiencies. For example the mean fermentation times of the Colombar juices could be reduced from 64 days to 23 days with a combined addition of water-soluble nutrients and unsaturated fatty acids and ergosterol. The most active components in this respect were ergosterol and unsaturated fatty acids.

TABLE 3

Effect of water-soluble nutrients, unsaturated fatty acids and ergosterol on fermentation time (Ft 0-99\%) of de-aerated juice filtrates of three grape culitvars*

\begin{tabular}{|c|c|c|c|c|c|c|c|c|c|}
\hline \multicolumn{4}{|c|}{ Juice addition } & \multicolumn{6}{|c|}{ Fermentation times (days) } \\
\hline \multicolumn{2}{|c|}{$\begin{array}{c}\text { Water-soluble } \\
\text { nutrients } \\
\left(\mathrm{mg} . \mathrm{NH}_{3} \cdot l^{-1}\right)\end{array}$} & \multicolumn{2}{|c|}{$\begin{array}{l}\text { Unsaturated } \\
\text { fatty acids }\end{array}$} & \multicolumn{2}{|c|}{$\begin{array}{c}\text { Cape } \\
\text { Riesling }\end{array}$} & \multicolumn{2}{|c|}{$\begin{array}{c}\text { Chenin } \\
\text { blanc }\end{array}$} & \multicolumn{2}{|c|}{ Colombar } \\
\hline A & B & $\begin{array}{c}\mathrm{C} \\
\left(\mathrm{mg} . l^{1}\right)\end{array}$ & $\begin{array}{c}\text { Ergos- } \\
\text { terol } \\
\left(\mathrm{mg} . l^{1}\right)\end{array}$ & $\mathrm{Ft}$ & $\mathrm{Cv}$ & $\mathrm{Ft}$ & $\mathrm{Cv}$ & $\mathrm{Ft}$ & $\mathrm{Cv}$ \\
\hline- & - & - & - & 32 & 22 & 46 & 30 & 64 & 50 \\
\hline 100 & - & - & - & 34 & 7 & 43 & 21 & 54 & 9 \\
\hline- & 100 & - & - & 34 & 10 & 44 & 9 & 56 & 15 \\
\hline- & - & 80 & - & 28 & 11 & 35 & 16 & 47 & 18 \\
\hline- & - & 80 & 6,7 & 24 & 5 & 29 & 21 & 32 & 12 \\
\hline- & 100 & 80 & 6,7 & 21 & 3 & 28 & 17 & 23 & 39 \\
\hline
\end{tabular}

*6 Cape Riesling, 13 Chenin blanc and 8 Colombar juices.

A: A mixture of $0,4 \mathrm{~g}$ di-ammonium phosphate, $0,45 \mathrm{mg}$ thiamine and $0,07 \mathrm{mg}$ biotin. $l^{1}$.

B: Yeast extract, peptone, malt extract and clarified tomato juice, individually and in combination had about the same effect and results were consequently combined.

C: Oleic, linoleic and linolenic acids individually and in combination, had about the same fermentation promoting effect and results were therefore combined.

Cv: Coefficient of variation $(\%)$ 
TABLE 4

The effect of additions of yeast nutrients to juices in three classes of fermentation time (Ft 0-99\%) viz. non-retarded, retarded and lagging fermentations*

\begin{tabular}{|c|c|c|c|c|c|c|c|c|c|}
\hline \multicolumn{4}{|c|}{ Juice additions } & \multicolumn{6}{|c|}{ Fermentation times (days) } \\
\hline \multicolumn{2}{|c|}{$\begin{array}{c}\text { Water-soluble } \\
\text { nutrients } \\
\left(\mathrm{mg} . \mathrm{NH}_{3} \cdot l^{-1}\right)\end{array}$} & \multicolumn{2}{|c|}{$\begin{array}{l}\text { Unsaturated } \\
\text { fatty acids }\end{array}$} & \multicolumn{2}{|c|}{ Non-retarded } & \multicolumn{2}{|c|}{ Retarded } & \multicolumn{2}{|c|}{ Lagging } \\
\hline $\mathrm{A}$ & $\mathrm{B}$ & $\begin{array}{c}\mathrm{C} \\
\left(\mathrm{mg} . l^{-1}\right)\end{array}$ & $\begin{array}{l}\text { Ergos- } \\
\text { terol } \\
\left(\mathrm{mg} . l^{-1}\right) \\
\end{array}$ & $\mathrm{Ft}$ & $\mathrm{Cv}$ & $\mathrm{Ft}$ & $\mathrm{Cv}$ & $\mathrm{Ft}$ & $\mathrm{Cv}$ \\
\hline $\begin{array}{l}\overline{100} \\
- \\
- \\
-\end{array}$ & $\begin{array}{l}- \\
\overline{100} \\
- \\
\overline{100}\end{array}$ & $\begin{array}{l}- \\
\overline{-} \\
\overline{80} \\
80 \\
80\end{array}$ & $\begin{array}{l}- \\
- \\
- \\
\overline{6,7} \\
6,7\end{array}$ & $\begin{array}{l}35 \\
36 \\
36 \\
29 \\
26 \\
24\end{array}$ & $\begin{array}{r}17 \\
12 \\
9 \\
13 \\
11 \\
6\end{array}$ & $\begin{array}{l}49 \\
40 \\
44 \\
37 \\
27 \\
20\end{array}$ & $\begin{array}{l}10 \\
11 \\
12 \\
16 \\
13 \\
23\end{array}$ & $\begin{array}{l}85 \\
67 \\
74 \\
58 \\
42 \\
27\end{array}$ & $\begin{array}{r}29 \\
7 \\
16 \\
22 \\
12 \\
39\end{array}$ \\
\hline
\end{tabular}

*The number of juices in the three groups were 17,8 and 7 respectively and the juices were selected from all three cultivars.

A: A mixture of $0,4 \mathrm{~g}$ di-ammonium phosphate, $0,45 \mathrm{mg}$ thiamine and $0,07 \mathrm{mg}$ biotin $l^{1}$.

B: Yeast extract, peptone, malt extract and clarified tomato juice, individually and in combination had about the same effect and results were consequently combined.

C: Oleic, linoleic and linolenic acids individually and in combination, had about the same fermentation promoting effect and results were therefore combined.

$\mathrm{Cv}$ : Coefficient of variation (\%)

Only in the case of Colombar could the fermentation supporting qualities of juices be improved by additions of di-ammonium phosphate and preparations rich in assimilable nitrogen compounds, such as yeast extract, peptone and tomato juice which also contained fatty acids but their effect with respect to fermentation appears minimal (Table 3 ).

The combined nitrogen/fatty acid fermentation supporting effect, occurs regardless of cultivar. In Table 4 it is shown that the effect of these additions is most pronounced in those juices where the most serious lagging occurs, indicating that they were indeed lacking specifically in these unsaturated lipids and to a lesser degree in assimilable nitrogen.
Table 5 shows that these juice deficiencies were not affected by grape maturity. They were eliminated at both high and low sugar concentrations by a combination of assimilable nitrogen, unsaturated fatty acids and ergosterol.

Unsaturated lipid requirements of yeasts:

In Table 6 it is shown,

1. that $22 \mathrm{mg} . \mathrm{l}^{-1} \mathrm{of}$ unsaturated fatty acids appeared to be relatively close to an optimal required concentration since a further increase did not cause a clear corresponding decrease in Ft 5-50 or Ft 0-99;

2. that the effect of ergosterol in combination with unsaturated fatty acids and, provided that it is supplied

TABLE 5

Effect of additions of yeast nutrient on the fermentation time (Ft 0-99\%) of low and high sugar content juice filtrates*

\begin{tabular}{|c|c|c|c|c|c|c|c|}
\hline \multicolumn{4}{|c|}{ Juice additions } & \multicolumn{4}{|c|}{ Fermentation time (days) } \\
\hline \multicolumn{2}{|c|}{$\begin{array}{c}\text { Water-soluble } \\
\text { nutrients } \\
\left(\mathrm{mg} . \mathrm{NH}_{3} \cdot l^{-1}\right)\end{array}$} & \multicolumn{2}{|c|}{$\begin{array}{l}\text { Unsaturated } \\
\text { fatty acids }\end{array}$} & \multicolumn{2}{|c|}{$\begin{array}{l}\text { "Low sugar" } \\
\text { juices } \\
\left(160-194 \mathrm{~g} . l^{-1}\right)\end{array}$} & \multicolumn{2}{|c|}{$\begin{array}{l}\text { "High sugar" } \\
\text { juices } \\
\left(195-225 \mathrm{~g} . l^{-1}\right)\end{array}$} \\
\hline$A$ & $B$ & $\begin{array}{c}C \\
\left(m g . l^{1}\right)\end{array}$ & $\begin{array}{c}\text { Ergos- } \\
\text { terol } \\
\left(\mathrm{mg} . l^{-1}\right)\end{array}$ & $\mathrm{Ft}$ & $\mathrm{Cv}$ & $\mathrm{Ft}$ & $\mathrm{Cv}$ \\
\hline $\begin{array}{l}\overline{100} \\
- \\
- \\
-\end{array}$ & $\begin{array}{l}- \\
\overline{100} \\
- \\
\overline{100}\end{array}$ & $\begin{array}{l}- \\
- \\
- \\
80 \\
80 \\
80\end{array}$ & $\begin{array}{l}- \\
- \\
- \\
6,7 \\
6,7\end{array}$ & $\begin{array}{l}43 \\
34 \\
42 \\
35 \\
30 \\
24\end{array}$ & $\begin{array}{l}50 \\
12 \\
13 \\
16 \\
18 \\
30\end{array}$ & $\begin{array}{l}55 \\
54 \\
51 \\
41 \\
30 \\
25\end{array}$ & $\begin{array}{l}43 \\
15 \\
11 \\
16 \\
18 \\
40\end{array}$ \\
\hline
\end{tabular}

*Seventeen juice samples in the "low sugar" group and 15 in the "high sugar" group.

A: A mixture of $0,4 \mathrm{~g}$ di-ammonium phosphate, $0,45 \mathrm{mg}$ thiamine and $0,07 \mathrm{mg}$ biotin. $l^{1}$.

B: Yeast extract, peptone, malt extract and clarified tomato juice, individually and in combination had about the same effect and results were consequently combined.

C: Oleic, linoleic and linolenic acids, individually and in combination, had about the same fermentation promoting effect and results were therefore combined.

Cv: Coefficient of variation $(\%)$ 


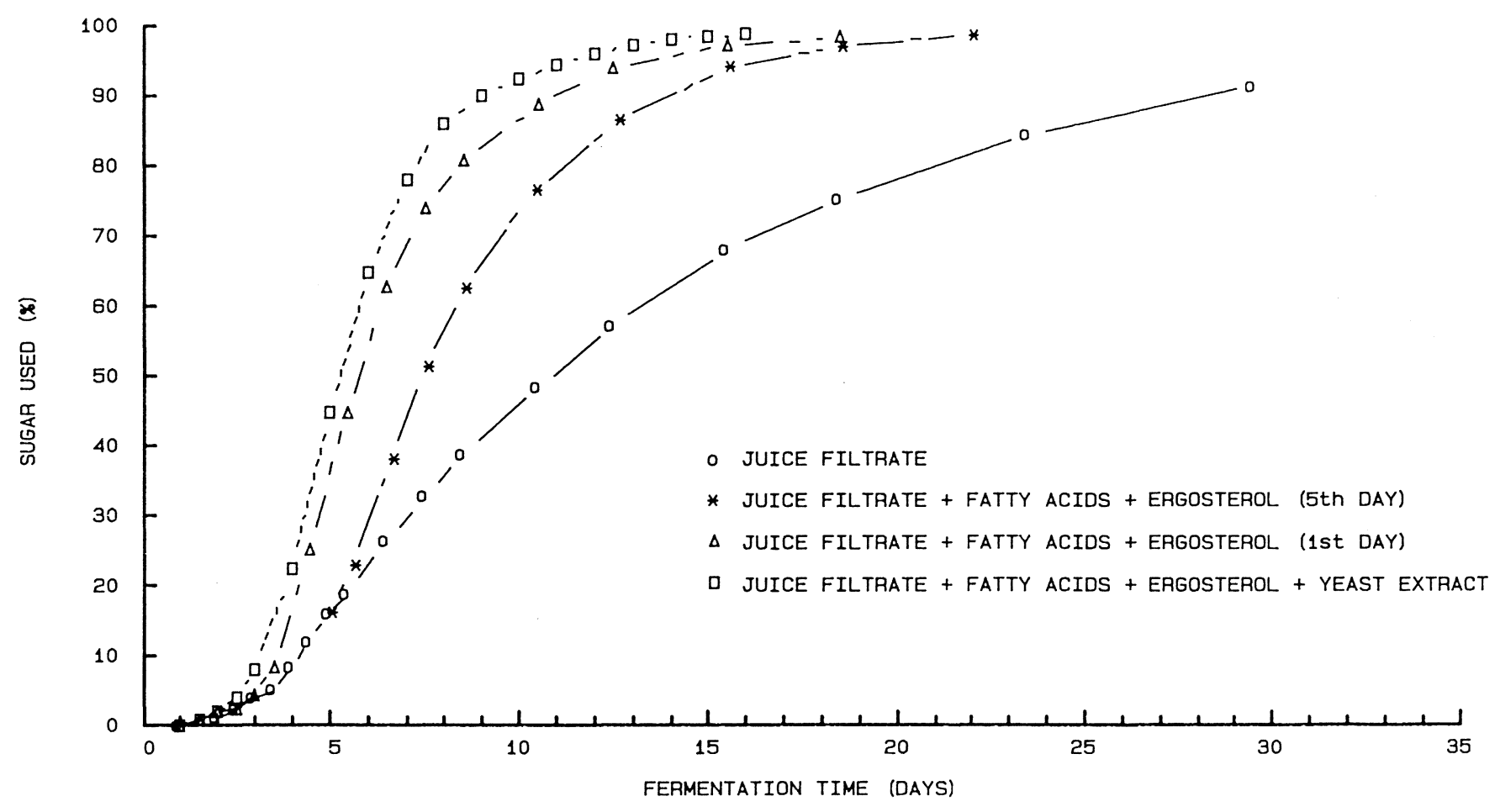

FIG. 1

Fermentation curves of juice filtrates with additions of yeast extract, unsaturated fatty acids and ergosterol at inoculation and on the fifth day thereafter. The percentage sugars used was derived from total $\mathrm{CO}_{2}$ mass loss, reducing sugar remaining and $\mathrm{CO}_{2}$ mass losses in the interim period.

in a finely dispersed and absorbable form, is already pronounced at a level of $1,7 \mathrm{mg} . \mathrm{l}^{-1}$. The concentration range used here viz. from 1,7 to $6,7 \mathrm{mg} . l^{-1}$ is approximately in line with the nutritional requirements for the proliferating yeast as determined by Strydom et al., (1982).

\section{Correction of retarded fermentation by addition of un-} saturated lipids:

In Fig. 1 it is shown that fermentation rate can be stimulated on the fifth day after inoculation by an ad-

\section{TABLE 6}

The effect of three concentration levels of unsaturated fatty acids and ergosterol on the fermentation time $(\mathrm{Ft})$ of grape juice filtrates*

\begin{tabular}{c|c|c|c|c|c}
\hline \multicolumn{2}{c|}{ Additions } & \multicolumn{3}{c}{ Fermentation time (days) } \\
\hline $\begin{array}{c}\text { Unsaturated } \\
\text { fatty acids } \\
\left(\text { mg. } l^{-1}\right)\end{array}$ & Ergosterol & Ft 5-50 & $\mathrm{Cv}$ & Ft 0-99 & $\mathrm{Cv}$ \\
\hline 0 & $\left(\mathrm{mg} . l^{-1}\right)$ & & & & \\
20 & 0 & 7,1 & 5,0 & 50 & 0 \\
40 & 0 & 4,9 & 0,7 & 42 & 1,7 \\
80 & 0 & 4,9 & 2,7 & 42 & 2,4 \\
20 & 0 & 4,6 & 7,2 & 38 & 8,7 \\
40 & 1,7 & 4,1 & 1,7 & 35 & 0 \\
80 & 3,3 & 3,5 & 3,1 & 30 & 0 \\
\hline
\end{tabular}

*Two parallel fermentation series with Chenin blanc and Colombar juices, enriched with di-ammonium phosphate at $0,4 \mathrm{mg} \cdot \mathrm{l}^{1}$.

**A mixture of $20 \%$ oleic acid, $40 \%$ linoleic acid and $40 \%$ linolenic acids.

Cv: Coefficient of variation (\%). dition of the unsaturated fatty acids plus ergosterol preparation. This effect was nearly equivalent to that of the same additions at the time of inoculation. A marked improvement in fermentation rate was brought about by the unsaturated lipids even at a relatively late stage of fermentation. This effect could not be achieved by the sole addition of large amounts of dispersed and absorbable ergosterol, under similar conditions (Houtman \& Du Plessis, 1981).

\section{CONCLUSION}

It was evident from this study that clarification of juice can remove substances which are essential for yeast proliferation. This effect can radically decrease fermentation rate but can differ between cultivars. Since a rapid, sound fermentation is important to wine makers, it appears necessary that the effect of normal cellar practices of juice clarification on the removal of fermentation promoting substances be investigated.

\section{LITERATURE CITED}

ARIES, V. \& KIRSOP, B.H., 1977. Sterol synthesis in relation to growth and fermentation by brewing yeasts inoculated at different concentrations. J. Inst. Brew. 83, 220-223.

ARIES, V. \& KIRSOP, B.H., 1978. Sterol biosynthesis by strains of Saccharomyces cerevisiae in the presence and absence of dissolved oxygen. J. Inst. Brew. 84, 118-122.

BACH, H.-P. \& HOFFMANN, P., 1979. Versuche zur Frage der Bentonitzugabe zum Most. Weinwirtschaft 115, 1119-1132.

BERTRAND, A., MARLY-BRUGEROLLE, C. \& SARRE, C., 1978. Influence de débourbage des moûts et du sulfitage sur les teneurs en substances volatiles des vins et des eaux-de-vie. I. Etude des vins. Conn. Vigne Vin 12, 35-48. 
BERTRAND, A. \& MIELE, A., 1984. Influence de la clarification du mout de raisin sur la teneur en acides gras. Conn. Vigne Vin, 18, 293-297.

BIZEAU, C., 1963. Etudes des facteurs limitant la croissance des levures dans les moûts de "Clairette" et de Muscat blanc à petits grains". Ann. Technol. Agricole, 12, 247-276 (Abstr. Vitis 4, 431, 1964).

BRÉCHOT, P., CHAUVET, J., CROSON, M. \& IRRMANN, R. 1966. Extrait de pruine de raisin, facteur de croissance anaérobie de la levure cultivée sur moût de raisin. C.R. Hebd. Seances Acad. Sci. (Paris). 1004-1006 (Abstr. Vitis 6, 449, 1967).

BRÉCHOT, P., CHAUVET, J., DUPUY, P., CROSON, M. \& RABATU, A., 1971a. Acide oleanique, facteur de croissance anaérobie de la levure de vin. C.R. Hebd. Seances Acad. Sci. (Paris). 272, 890-893 (Abstr. Vitis 10, 269, 1971).

BRÉCHOT, P., CHAUVET, J., DUPUY, P., CROSON, M. \& RABATU, A., 1971b. Acide oleanique, facteur de croissance anaérobie de la levure de vin. Ann. Technol. Agric. (Paris) 20, $103-110$.

BUTEAU, C., DUITSCHAEVER, C.L. \& ASHTON, G.C., 1979. Vinification of three white grape varieties by three different methods. I. Fermentation process and wine composition. II. Sensory evaluation of the wines. Am. J. Enol. Vitic. 30, 139-145, 146-151.

CASTINO, M., UBIGLI, M. \& DI STEFANO, R., 1980. Die Mostvorklärung von Weissweinen. Vignevini (Bologna) 7, 33-41 (Abstr. Vitis 20, 72, 1984)

DAVID, M.H., 1974. Absence of nutritional requirements for unsaturated fatty acids by brewers yeast in malt wort. J. Inst. Brew. 80, $80-81$

DAVID, M.H. \& KIRSOP, B.H., 1973. Yeast growth in relation to the dissolved oxygen and sterol content of wort. J. Inst. Brew. 79, 20-25.

GENEIX, C., LAFON-LAFOURCADE, S. \& RIBÉREAUGAYON, P., 1983. Les causes la prévention et le traitement des arrets de la fermentation alcoolique. Conn. Vigne Vin 17, 205217

GROAT, M. \& OUGH, C.S., 1978. Effects of insoluble solids added to clarified musts on fermentation rate, wine composition and wine quality. Am. J. Enol. Vitic. 29, 112-119.

HAUBS, H., 1976. Klärung von Most und Wein in Mittel- und Kleinbetrieb. Deutsche Weinbau 25, 992.

HAUKELI, A.D. \& LIE, S., 1973. Inductive effects of oxygen and yeast fermentation in glucose and maltose media. J. Inst. Brew. 79, 55-61.

HOUTMAN, A.C., MARAIS, J. \& DU PLESSIS, C.S., 1980a. Factors affecting the reproducibility of fermentation of grape juice and of the aroma composition of wines. I. Grape maturity, sugar, inoculation concentration, aeration, juice turbidity and ergosterol. Vitis 19, 37-54

HOUTMAN, A.C., MARAIS, J. \& DU PLESSIS, C.S, 1980b. The possibilities of applying present-day knowledge of wine aroma components: Influence of several juice factors on fermentation rate and ester production during fermentation. S. Afr. J. Enol. Vitic. 1, 27-33.

HOUTMAN, A.C. \& DU PLESSIS, C.S, 1981. The effect of juice clarity and several conditions promoting yeast growth on fermentation rate, the production of aroma components and wine quality. S. Afr. J. Enol. Vitic. 2, 71-81.

HOUTMAN, A.C. \& DU PLESSIS, C.S., 1986. The effect of grape cultivar and yeast strain on fermentation rate and concentration of volatile components in wine. S. Afr. J. Enol. Vitic. 7, 14-20.

KIRSOP, B.H., 1978. Pitching rate. Brewers-Digest July, 28-32.

LAFON-LAFROUCADE, S., 1980. Connoissances récentes sur les accidents de la fermentation. Rev. Franc. Oenol. 16, 63-75 (Abstr. Vitis, 20, 185, 1981)

LAFON-LAFOURCADE, S., 1984. Souches de levure. Bull. de l'O.I.V. 57, 185-204

LAFON LAFOURCADE, S., GENEIX, C. \& RIBÉREAUGAYON, P., 1984. Les modalites de mise en oeuvre des ecorces de levure en vinification. Conn. Vigne Vin 18, 111-125.

LAFON-LAFOURCADE, S., \& RIBÉREAU-GAYON, P., 1979 Quelques observations sur les problemes microbiologiques de la vinification en blanc. Conn. Vigne Vin 13, 51-76.

LAFON-LAFOURCADE, S., LARUE, F., BRÉCHOT, P. \& RIBÉREAU-GAYON, P., 1977. Les stéroïdes "facteurs de survie" des levures au cours de la fermentation alcoolique du moût de raisin. C.R. Hebd. Seances Acad. Sci. Ser. D.. 284. 1939-1942.

LARUE, F., LAFON-LAFOURCADE, S. \& RIBÉREAU-
GAYON, P., 1978. Relations entre la teneur cellulaire en stérols et l'activité fermentaire des levures dans le moût de raisin. Role fonctionel des steroïdes. C.R. Acad. Sci. 287 D, 1445-1448.

LARUE, F., LAFON-LAFOURCADE, S. \& RIBÉREAUGAYON, P., 1979. Les différents rôles fonctionnels des stéroïdes sur les levures dans le moût de raisin en fermentation: notion du facteur de survie. Ann. Microbiol. 130 A, 231-234.

LARUE, F., GENEIX, C., LAFON-LAFOURCADE, S., BERTRAND, A. \& RIBÉREAU-GAYON, P., 1984. Premières observations sur le mode d'action des écorces de levure. Conn. Vigne Vin 18, 155-163.

LEWIS, M.J. \& ENEVOLDSEN, B.S., 1973. Yeast growth and beer flavour. J. Inst. Brew. 79, 341

LINNANE, W. \& KELLERMAN, G.M., 1971. Account of the role of unsaturated fatty acids in the control of the fermentative and oxidative activity of yeast. J. Inst. Brew. 77, 6 .

MINàRIK, E., 1983. Zur aktivierung der alkoholischen Gärung zuckerreicher Moste. Wein-Wiss. 38, 202-209.

NORDHEIM, W., 1965. Über die Bedeutung der Lipide für den Stoffwechsel der Hefen. Brauwiss. 18, 125-132, 215-223.

NORDSTRÖM, K., 1964. Formation of esters from acids by brewer's yeast. IV. Effect of higher fatty acids and toxicity of lower fatty acids. J. Inst. Brew. 70, 233-242.

OUGH, C.S., 1964. Fermentation rates of grape juice. I. Effects of temperature and composition on white juice fermentation rates. Am. J. Enol. Vitic. 15, 167-177.

OUGH, C.S, 1966a. Fermentation rates of grape juice. II. Effect of initial Brix, $\mathrm{pH}$ and fermentation temperature. Am. J. Enol. Vitic. 17, 20-26.

OUGH, C.S., 1966b. Fermentation rates of grape juice. III. Effect of initial ethanol, $\mathrm{pH}$ and fermentation temperature. Am. J. Enol. Vitic. 17, 74-81.

OUGH, C.S. \& AMERINE, M.A., 1961. Studies with controlled fermentation. VI. Effects of temperature and handling on rates, composition and quality of wines. Am. J. Enol. Vitic. 12, 117 128.

OUGH, C.S. \& AMERINE, M.A., 1966. Fermentation rates of grape juice. IV. Compositional changes affecting prediction equations. Am. J. Enol. Vitic. 17, 163-173.

OUGH, C.S, \& KUNKEE, R.E., 1967. Effects of acid additions to grape juice on fermentation rates and wine qualities. Am. J. Enol. Vitic. 18, 11-17.

OUGH, C.S. KUNKEE, R.E., 1968. Fermentation rates of grape juice. V. Biotin content of juice and its effects on alcoholic fermentation rate. Appl. Microbiol. 16, 572-576 (Abstr. Vitis 7, 277, 1968).

PETRO, I., 1965. La stabilisation proteique précoce provoqué par le traitement du moût par la bentonite. Borgazdasàg (Budapest) 13, 151 (Abstr. Vitis. 6, 342, 1967.

PONOMARCHENKO, V.B. \& ALBOT, I.V., 1976. Einflüss von bentonit auf den Gärverlauf des Mostes und auf die Veränderung des Stickstoffkomplexes. Sadovod. Vinograder $i$ Vinodel. Moldavii 31, 24-28 (Abstr. Vitis. 15, 147, 1976)

RIBERÉAU-GAYON, P., LAFON-LAFOURCADE, S. \& BERTRAND, A. 1975. Le debourbage des moûts de vendange blanche. Conn. Vigne Vin 9, 117-139.

RIBÉREAU-GAYON, P., SUDRAUD, P. \& LAFON-LAFOURCADE, S., 1978. Incidence des techniques de vinification sur la constitution des vins blancs. Conn. Vigne Vin 12, 49-56.

RIBERÉAU-GAYON, P., LAFON-LAFOURCADE, S., DUBOURDIEU, D., LUCMARARET, V. \& LARUE, F., 1979. Métabolism de Saccharomyces cerevisiae dans les moûts de raisins parasités par Botrytis cinerea. Inhibition de la fermentation; formation d'acide acétique et de glycérol. C.R. Acad. Sci. 289 D, 441-444.

SAPIS-DOMERCO, S. \& PEYNAUD, E., 1973. Influence de divers procédés de thermovinification sur la microflore levurienne. Conn. Vigne Vin 7, 189-201.

SINGLETON, V.L., SIEBERHAGEN, H.A., DE WET, P. \& VAN WYK, C.J., 1975. Composition and sensory qualities of wines prepared from white grapes by fermentation with and without grape solids. Am. J. Enol. Vitic. 26, 62-69.

SOUFLEROS, E. \& BERTRAND, A., 1980. Incidence de l'action conjugée de la température de fermentation et de l'acidité du milieu sur les teneurs en substances volatiles fermées par les levures. Conn. Vigne Vin 14, 97-109.

STRYDOM, M. KIRSCHBAUM, A.F. \& TROMP, A., 1982. Ergosterol concentration of several different Saccharomyces cerevisiae yeast strains. S. Afr. J. Enol. Vitic. 3, 23-28. 
TRAVERSO-RUEDA, S. \& KUNKEE, R.E., 1982. The role of sterols on growth and fermentation of wine yeasts under vinification conditions. Dev. Ind. Microbiol. 23, 131-134 (Abstr. Am. J. Enol. Vitic, 35, 56 1984).

TROMP, A., 1984. The effect of yeast strain, grape solids, nitrogen and temperature on fermentation rate and wine quality. S. Afr. J. Enol. Vitic. 5, 1-6.

TSAKOV. D., GORINOVA, N., MESROB, B. \& SPIROV, N., 1979. Einflüss des Bentonites und der Gärungstemperatur auf den Gehalt an hochmolekularen Stoffen in Most und Wein. Lozar, Vinar. (Sofia) 28, 23-31 (Abstr. Vitis 1, 435, 1979).

VOS, P.J.A. \& GRAY, R.S., 1979. The origin and control of hydro- gen sulfide during fermentation of grape must. Am. J. Enol. Vitic. 30, 187-197.

WENZEL, K. \& DITTRICH, H.H., 1978. Zur Beeinflussung der Schwefelwasserstoff-Bildung der Hefe durch Trub, Stickstoffgehalt, molekularen Schwefel und Kupfer bei der Vergärung von Traubenmost. Wein-Wiss. 33, 200-214

WILLIAMS, J.T., OUGH, C.S. \& BERG, H.W., 1978. White wine composition and quality as influenced by method of must clarification. Am. J. Enol. Vitic. 29, 92-96.

WUCHERPFENNIG, K. \& BRETTHAUER, G., 1970. Über die Bildung von flüchtigen Aromastoffen in Traubenwein in Abhängigkeit von der Mostvorbehandlung sowie von der verwendeten Heferasse. Mitt. Klosterneuburg 20, 36-46. 